\title{
O Fascínio de Ser Professor
}

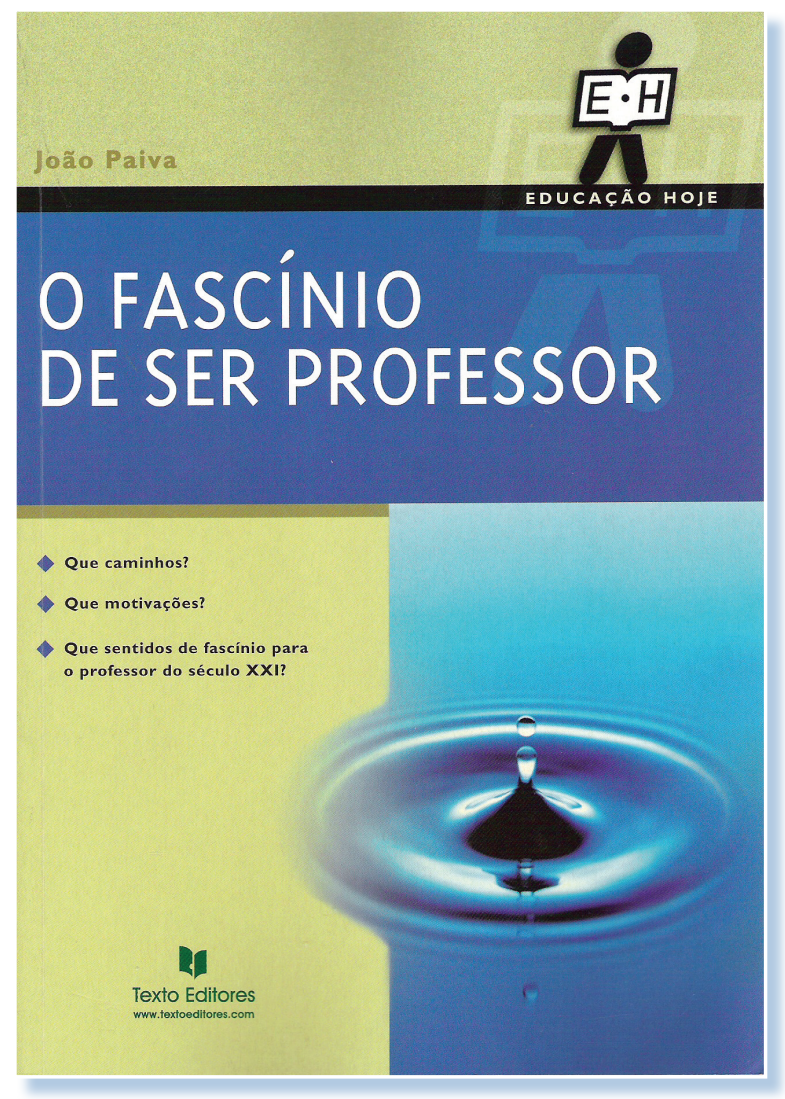

António Gedeão, em "Poema da Selva" diz-nos:

(...) Andar no mundo é como atravessar o continente negro do berço à contracosta.

Vai-se crescendo e andando. Sonhando enquanto é tempo (...)

João Paiva sonha com uma escola diferente e, para o conseguir, apresenta uma "fórmula" traduzida na frase: "O fascínio é o eixo que faz mover a escola e, assim, anima o mundo".

É precisamente com esta frase que termina o seu livro "O fascínio de ser professor" editado em 2007 pela Texto Editores.

Mas para que os leitores não criem falsas expectativas vai deixando no ar algumas advertências que, por vezes, se entrelaçam.

Não se trata de um livro de receitas, é o próprio autor quem no-lo diz.

(...) não tenho comigo receitas para resolver os complexos problemas da educação. Mas o meu "não baixar braços" dirige-se, com insistência, senão mesmo teimosia, a enfatizar o fascínio de ser professor (...).

Também não se trata de um livro académico. $E$ cito novamente o autor.

“(...) relato aqui a minha experiência, refiro a minha sensibilidade, as minhas dúvidas, até as minhas inconsistências, e as minhas conviçcões e sentidos de urgência para a educação. Não sou, contudo, categórico, nem acho, obviamente, que ser-se professor é necessariamente "ir por aqui" (...).

No entanto, João Paiva vai deixando aqui e ali alertas extraordinariamente importantes, como por exemplo:

(...) nivelar por baixo, como se tem vindo a fazer na escola portuguesa é sempre um mau princípio (....)

(...) criem-se alternativas mas "deixar andar" não pode nunca ser o caminho, seja em nome de que sucesso for $(. .$.

(...) um ensino de ciências sem experimentação é como o ensino da lite- ratura sem livros $(. .$.

(...) pedagogicamente é tão frágil pensar sem fazer como fazer sem pensar (...)

(...) sou entusiasta do uso das TIC mas arrepio-me quando alguém tende a confundir tal apologia com o desprivilégio da experimentação (...)

(...) a um professor fica sempre meIhor perguntar que afirmar. Afirmar o que pode ser conquistado pelo aluno é tentação a combater (...).

(... ) a grande arma contra a indisciplina ainda é o diálogo (...)

(...) podem mudar todos os decretos-lei e oferecerem-se óptimas condições logísticas e infra-estruturais, mas faltando o entusiasmo dos professores, falta a alma da escola e a educação esmorecerá como plantas sem água (...)

O recurso a metáforas, uma linguagem simples, ilustrações do seu filho Afonso, simultaneamente ingénuas e esclarecedoras, tornam agradável a leitura deste livro.

Mas não se trata apenas de um livro que se lê com agrado. Num conjunto de vinte secções, de títulos sugestivos (por exemplo razão/afectos, ajuda/ /autonomia, autoridade/diálogo) João Paiva apresenta sob a forma de uma dicotomia, não necessariamente um antagonismo, um conjunto de reflexões sobre vários temas que atravessam a função do professor em geral e do professor de Química em particular.

Em síntese, trata-se de um livro útil para qualquer professor e, direi mesmo, indispensável para aqueles que estão a iniciar a carreira, sejam ou não professores de Química. A uns e a outros deixo, como que em forma de mensagem, a palavra do autor.

(...) Estar na escola, como professor, é um privilégio não só para ensinar, mas para aprender e para perceber melhor o mundo em que vivemos. Por isso importa sempre recomeçar (...).

\section{Regina Gouveia}

Professora aposentada de Físico-Químicas no Ensino Secundário gouveias@tvtel.pt 